\title{
Phytoremediation Potential of Vetiver System Technology for Improving the Quality of Palm Oil Mill Effluent
}

\author{
Negisa Darajeh, ${ }^{1}$ Azni Idris, ${ }^{1}$ Paul Truong, ${ }^{2}$ Astimar Abdul Aziz, \\ Rosenani Abu Bakar, ${ }^{4}$ and Hasfalina Che Man $^{5}$ \\ ${ }^{1}$ Department of Chemical and Environmental Engineering, Faculty of Engineering, Universiti Putra Malaysia, \\ 43300 Serdang, Selangor, Malaysia \\ ${ }^{2}$ The Vetiver Network International, Asia and Oceania, Brisbane 4069, Australia \\ ${ }^{3}$ Malaysian Palm Oil Board (MPOB), Agro Product Unit, Engineering and Processing Division, Jalan Sekolah, \\ Pekan Bangi Lama, 43000 Kajang, Selangor, Malaysia \\ ${ }^{4}$ Department of Land Management, Faculty of Agriculture, Universiti Putra Malaysia, 43300 Serdang, \\ Selangor, Malaysia \\ ${ }^{5}$ Department of Biological and Agricultural Engineering, Faculty of Engineering, Universiti Putra Malaysia, \\ 43300 Serdang, Selangor, Malaysia \\ Correspondence should be addressed to Azni Idris; azni@eng.upm.edu.my
}

Received 3 October 2014; Revised 19 November 2014; Accepted 20 November 2014; Published 11 December 2014

Academic Editor: Steven L. Suib

Copyright (C) 2014 Negisa Darajeh et al. This is an open access article distributed under the Creative Commons Attribution License, which permits unrestricted use, distribution, and reproduction in any medium, provided the original work is properly cited.

Palm oil mill effluent (POME), a pollutant produced by the palm oil industry, was treated by the Vetiver system technology (VST). This technology was applied for the first time to treat POME in order to decrease biochemical oxygen demand (BOD) and chemical oxygen demand (COD). In this study, two different concentrations of POME (low and high) were treated with Vetiver plants for 2 weeks. The results showed that Vetiver was able to reduce the BOD up to $90 \%$ in low concentration POME and $60 \%$ in high concentration POME, while control sets (without plant) only was able to reduce $15 \%$ of BOD. The COD reduction was $94 \%$ in low concentration POME and 39\% in high concentration POME, while control just shows reduction of $12 \%$. Morphologically, maximum root and shoot lengths were $70 \mathrm{~cm}$, the number of tillers and leaves was 344 and 86 , and biomass production was $4.1 \mathrm{~kg} \mathrm{~m}^{-2}$. These results showed that VST was effective in reducing BOD and COD in POME. The treatment in low concentration was superior to the high concentration. Furthermore, biomass of plant can be considered as a promising raw material for biofuel production while high amount of biomass was generated in low concentration of POME.

\section{Introduction}

Clean water has increasingly become one of the rare valuable resources. Fast industrialization causes the production and release of considerable amounts of wastes in the water sources. The conventional water sources are easily contaminated by industries wastewater $[1,2]$. The palm oil industry, over the last four decades, has become one of the major agroindustries in Malaysia [3, 4]. The palm oil industry caused negative impact on the environment and it may contribute to the alarming increase in the environmental pollution [5]. The processing of palm oil produces large quantities of polluted wastewater commonly named as palm oil mill effluent (POME). POME is the liquid waste in the processing of oil extraction, washing, and cleaning processes. Up to $1.5 \mathrm{~m}^{3}$ of water is used to process one tone of fresh fruit bunch (FFB). From this quantity, about $50 \%$ of the water results in the POME, the other $50 \%$ being lost as steam, mainly through sterilizer exhaust, piping leakages, and wash waters [6-9].

POME has been identified as the main sources of water pollution in Malaysia due to high biochemical oxygen demand (BOD) and chemical oxygen demand (COD) that causes reduction of the biodiversity and ability of aquatic ecosystems. Department of Environment (DOE) enforces 
a regulation under the Environmental Quality Act (1997) for the discharge of effluent from the palm oil industry. DOE requires an effective management system in order to treat and dispose of POME with the goal of environmental conservation and increasing the quality of river water.

Several treatment technologies have been developed and applied by palm oil mills to treat POME, such as anaerobic digestion $[10,11]$, membrane technology [12], aerobic activated sludge reactor [3], and evaporation method [13]. These conventional treatment systems frequently encounter problems associated to their long hydraulic retention time (HRT) and large space requirement; these could be problems with increasing production of POME. The challenge of environmental engineers and scientists is to develop effective and simple methods for treatment of industrial wastewater.

Nowadays phytoremediation as a green technology is one of the main environmentally friendly technologies that scientists are using in their researches. Phytoremediation is the direct use of green plants to clean up contaminated water, soils, or sediments. Phytoremediation is a new, cost effective, aesthetically pleasing, and low cost suitable solution for many environmental problems across the world [14-16]. Suitable plant species used for phytoremediation should have high uptake of both organic and inorganic pollutants, grow well in polluted water, and be easily controlled in quantity spreading dispersion. Furthermore, the plants should not only accumulate, reduce, or volatilize the contaminants but also grow fast in a range of different conditions and lends to harvesting easily $[17,18]$.

Vetiver grass (Chrysopogon zizanioides L.) belongs to the same grass family as maize, sorghum, sugarcane, and lemon grass (Figure 1). It was first used for soil and water conservation purposes by the World Bank. However, in the last two decades, Vetiver role has been successfully extended to environmental protection, particularly in the field of wastewater treatment, due to its prominent morphological and physiological characteristics and tolerance to adverse conditions [19].

Application of the Vetiver system for wastewater treatment is a new and innovative phytoremedial technology. It is a green and environmental friendly wastewater treatment technology as well as a natural recycling method. In the process of treatment, the Vetiver plant absorbs essential plant nutrients such as nitrogen $(\mathrm{N})$, phosphorus $(\mathrm{P})$, and cations and stores them for other uses.

The end product has provided high nutrient material for animal feed, mulch for gardens, roof thatching, handicrafts (ropes, mats, hats, and baskets) raw material for making pulp, and paper and material for organic farming [20] and recently extended to biofuel and carbon sequestration. Despite the potential advantages of Vetiver grass for the treatment of wastewaters, there has been very little information published to date about hydroponic treatment performance by Vetiver. The novelty of this work is the use of Vetiver grass for the first time for treatment of POME. In the present work, Vetiver first was grown on hydroponic solution to obtain well-developed

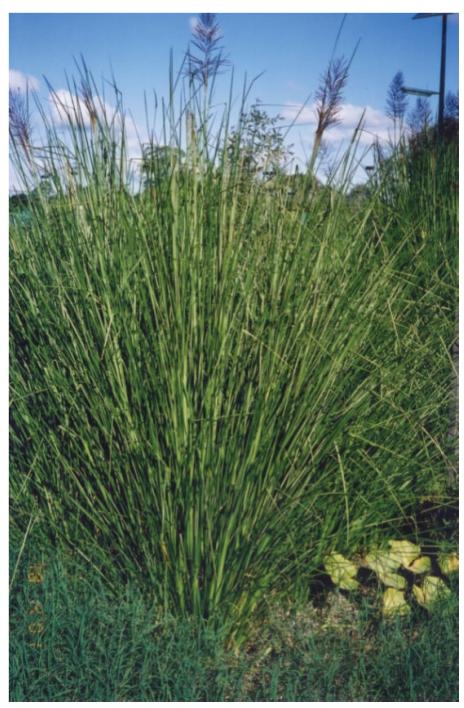

Figure 1: Vetiver grass (Chrysopogon zizanioides L.).

roots and then transfer them to two different concentrations of POME, to demonstrate the potential of Vetiver grass in reducing the biological oxygen demand (BOD) and chemical oxygen demand (COD) and investigate biomass production.

\section{Materials and Chemical}

2.1. Batch Studies. The experiment consisted of two sets of three rectangular plastic containers $(0.3 \mathrm{~m}$ length $\times 0.3 \mathrm{~m}$ width $\times 0.5 \mathrm{~m}$ depths), capacity of $45 \mathrm{~L}$ and surface area of $0.09 \mathrm{~m}^{2}$. One set contained undiluted POME (high concentration POME) and another set had the POME diluted (low concentration POME) with tap water in a 1 (POME) : 9 (water) ratio. Both diluted and undiluted treatments consisted of three subtreatments. These included culture of Vetiver with density of 15 tillers, culture of Vetiver with 30 tillers, and a container with no Vetiver, referred to as control. Vetivers were obtained from a commercial nursery, Humibox (M) Sdn. Bhd, Malaysia. To allow for some adaption, Vetivers were grown in a hydroponic solution (N, P, K, $18: 18: 18)$, for five weeks until adequate roots and shoots development were obtained (Figure 2). Polystyrene sheets with a dimension of $29 \times 29 \times 5 \mathrm{~cm}$ (length $\times$ width $\times$ thickness) were placed on the plastic containers surface as the floating platform to support Vetiver plants.

Vetiver slips were planted into the hole of the polystyrene platform with approximately $8 \mathrm{~cm}$ of roots submerged in POME (Figure 3). Aeration facilitates aerobic degradation of organic materials by maintaining oxygen concentration in the wastewater. Several studies have been conducted to improve the quality of effluent from industrial sources using aerated systems [21-23]. Due to this reason, this setup continuously provided $3 \mathrm{~m} \mathrm{gL}^{-1}$ oxygen to the solution to maintain good bacterial growth. The experiment was carried out with aerobic condition for two weeks, in which observations were made of changes in appearance and growth of Vetiver plants. 

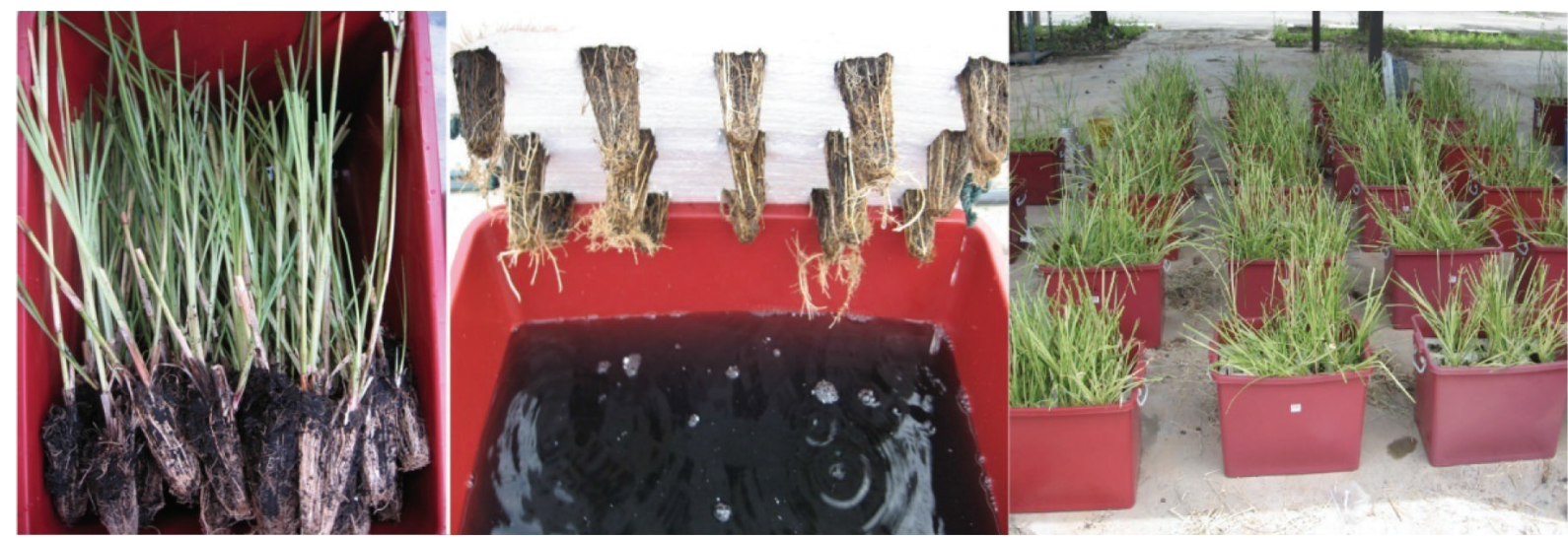

FIGURE 2: Vetiver planting slips in hydroponic solution.
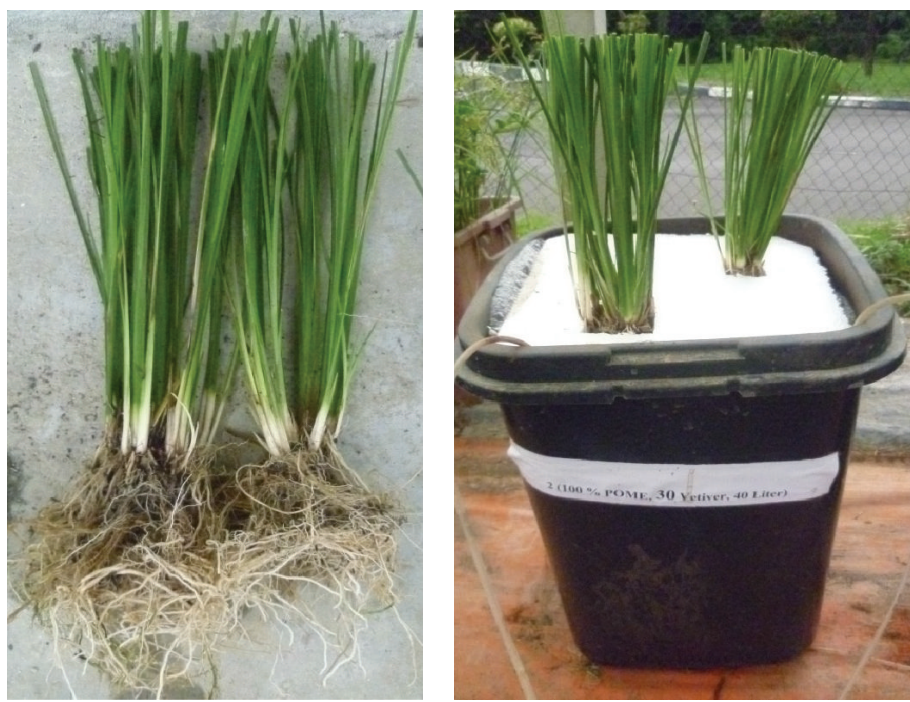

FiguRE 3: Vetivers after five weeks ready for experimentation.

TABLE 1: Characteristics of POME.

\begin{tabular}{lc}
\hline Parameter & Concentration \\
\hline $\mathrm{pH}$ & $6.5-7.5$ \\
Total suspended solid $(\mathrm{mg} / \mathrm{L})(\mathrm{TSS})$ & $750-800$ \\
$\mathrm{BOD}_{3}(\mathrm{mg} / \mathrm{L})$ & $350-400$ \\
$\mathrm{COD}(\mathrm{mg} / \mathrm{L})$ & $790-810$ \\
Total nitrogen $(\mathrm{mg} / \mathrm{L})$ & $400-450$ \\
Ammoniacal nitrogen $(\mathrm{mg} / \mathrm{L})$ & $295-310$ \\
Turbidity $(\mathrm{NTU})$ & $3300-3400$ \\
Color $(\mathrm{ADMI})$ & $3600-3700$ \\
\hline
\end{tabular}

The aeration was carried out using aquarium pump with a porous stone diffuser that was put at the bottom of container. The POME was collected from anaerobic treated pond at Labu Palm Oil Mill in Labu, Negri Sembilan, Malaysia. The characteristic is presented in Table 1 . The characteristics of POME highly depend on the operation process in
TABLE 2: Treatment combinations.

\begin{tabular}{|c|c|c|c|}
\hline POME concentration & $\mathrm{LCP}^{*}$ & $\mathrm{HCP}^{*}$ & Control \\
\hline Vetiver density & V30/V15** & V30/V15 & Control \\
\hline
\end{tabular}

Vetiver tillers.

the mill and seasonal changes in the palm crops. Table 2 shows the treatment combinations, where low concentrated POME (LCP) and high concentrated POME (HCP) are POME concentration and V30 and V15 are the number of Vetiver tillers.

At the beginning of the study whole Vetiver plants were collected; leaves were cut at surface level of polystyrene and rinsed thoroughly with deionized water, and used paper toweling to wiped leaves, and then they were weighed. Plant leaves were placed on the tray and dried in oven which was set at $70^{\circ} \mathrm{C}$. They were dried for 72 hours, then cooled 


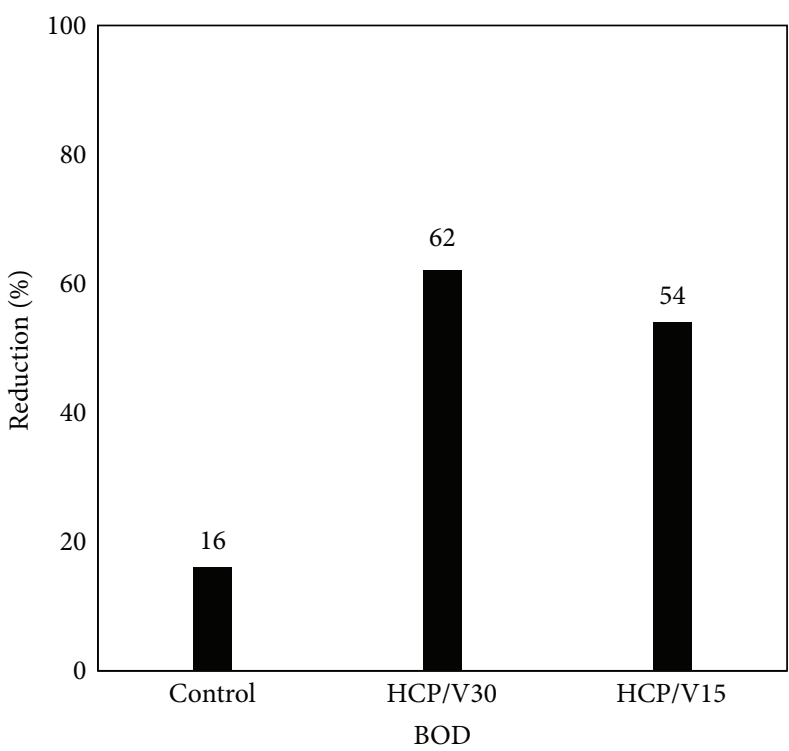

(a)

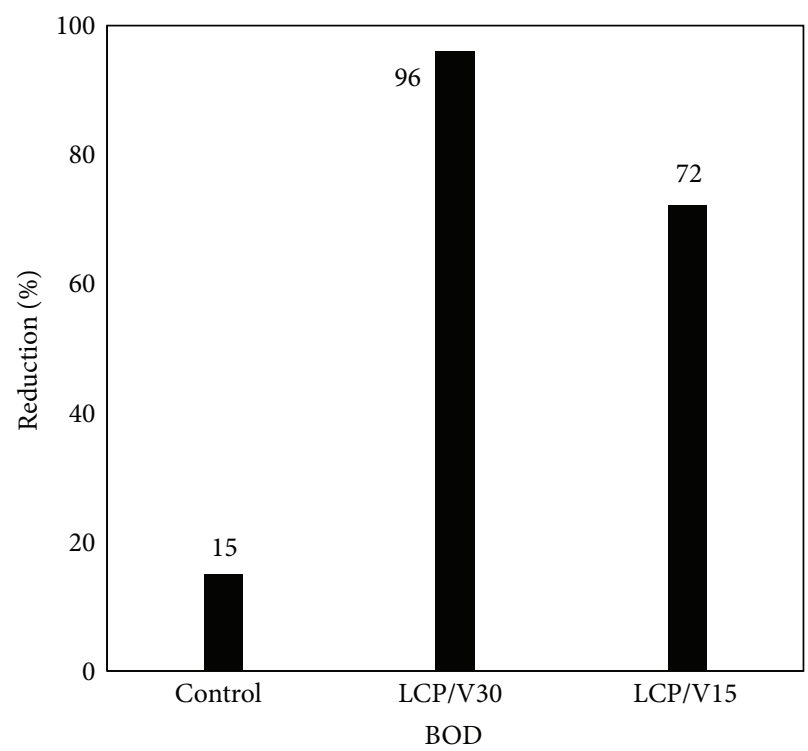

(b)

FIGURE 4: Reduction of BOD\%: (a) high concentration POME (HCP) and (b) low concentration POME.

in a desiccators jar, and reweighed. Biomass for leaves was calculated by the following formula:

$$
\text { Standing Biomass }=\frac{\text { Dry Weight }(\mathrm{kg})}{\text { Surface area }\left(\mathrm{m}^{2}\right)} \text {. }
$$

The morphological parameters such as the number of tillers, height of shoots, and length of roots were recorded and analyzed at the end of experimental period (14 days).

Reduction efficiencies of treatment system were calculated based on the following formula:

$$
\% \text { Removal Efficiency }=\left(\frac{C_{\text {inf }}-C_{\text {eff }}}{C_{\text {inf }}}\right) \times 100 \text {, }
$$

where $C_{\text {inf }}$ is initial parameter concentration and $C_{\text {eff }}$ is final parameter concentration.

2.2. Analytical Method. The treatments were evaluated by measuring parameters, which were consistently taken during midmorning. Samples were obtained by dipping a $100 \mathrm{~mL}$ graduated cylinder at three places across the surface of the container and combining them. The wastewater in each container was sampled 8 times over 14-day period, on days 0 , $2,4,6,8,10,12$, and 14 . Chemical oxygen demand (COD) and biological oxygen demand (BOD) were measured according to standard methods (APHA.1998).

\section{Result and Discussion}

3.1. Organic Reduction. The organic compounds reduction takes place with biological decomposition processes by microorganisms. Plant rhizosphere stimulates microbial activity and community density by providing root surface
TABLE 3: Reduction of BOD in high concentration POME with different Vetiver density.

\begin{tabular}{lccc}
\hline POME/Vetiver & BOD day 0 & $\begin{array}{c}\text { BOD after 14 } \\
\text { days }\end{array}$ & $\begin{array}{c}\text { BOD } \\
\text { reduction \% }\end{array}$ \\
\hline Control & 348 & 292 & 16 \\
HCP/V30 & 350 & 133 & 62 \\
HCP/V15 & 356 & 163.7 & 54 \\
\hline
\end{tabular}

area for their growth $[24,25]$. The organic strength of wastewater measured as biochemical oxygen demand (BOD) and chemical oxygen demand (COD). BOD assessment is one of the most widely used criteria for water quality [26]. BOD is the amount of dissolved oxygen (DO) that is used by microbial activity for the biochemical degradation of organic matter in water in a given time (usually 5 days) at a certain temperature $\left(20^{\circ} \mathrm{C}\right)$ in the dark place [27]. Effects of two parameters' concentration and Vetiver density on BOD reduction were investigated as follows.

3.2. Effect of Concentration on BOD Reduction. The level of contaminants will affect its uptake by Vetiver plant as shown in Figure 4. After two weeks of remediation, the highest reduction $\mathrm{BOD}$ was $\mathrm{LCP}$, with $96 \%$ of $\mathrm{BOD}$ reduction, while the HCP reduction was lower than LCP; it showed $62 \%$ of $\mathrm{BOD}$ reduction.

3.3. Effect of Vetiver Density on BOD Reduction. The number of Vetiver tillers will affect BOD reduction efficiency, as shown in Tables 3 and 4 after two weeks of remediation in both concentrations; reduction of BOD with 30 tillers of 


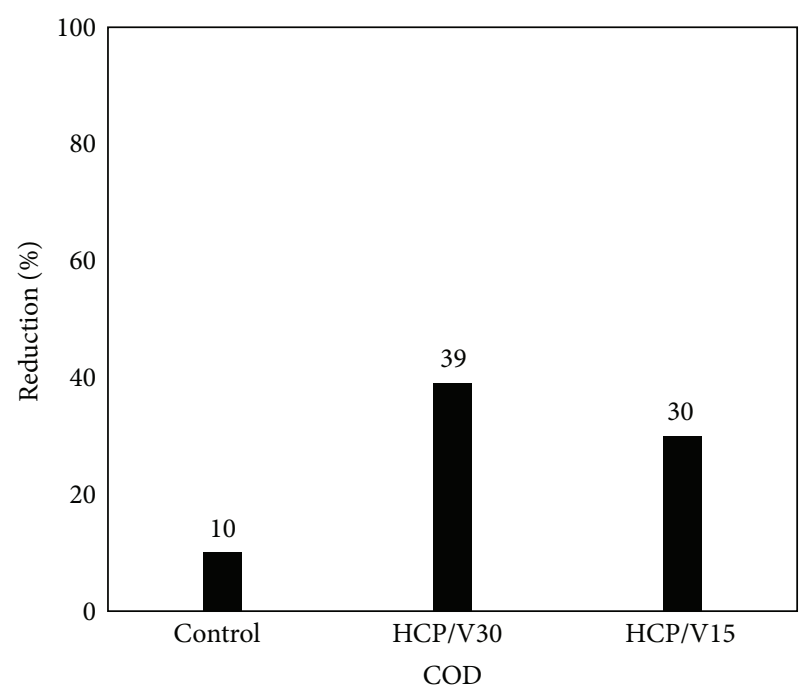

(a)

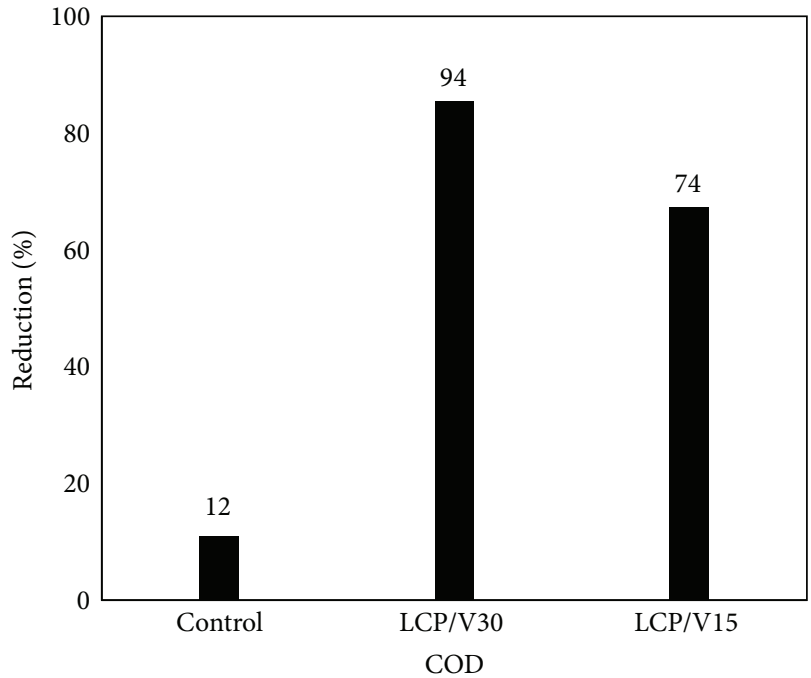

(b)

Figure 5: Reduction of COD\%: (a) high concentration POME and (b) low concentration POME.

TABLE 4: Reduction of BOD in low concentration POME with different Vetiver density.

\begin{tabular}{lccc}
\hline POME/Vetiver & BOD day 0 & $\begin{array}{c}\text { BOD after 14 } \\
\text { days }\end{array}$ & $\begin{array}{c}\text { BOD } \\
\text { reduction \% }\end{array}$ \\
\hline Control & 56 & 47.6 & 15 \\
LCP/V30 & 52 & 2 & 96 \\
LCP/V15 & 56 & 15.7 & 72 \\
\hline
\end{tabular}

Vetiver was higher than 10 Vetiver tillers. On concentration of LCP, with 15 tillers of Vetiver the reduction was $72 \%$, while in the same concentration but with 30 tillers of Vetiver the BOD reduction was $96 \%$. Also in concentration of HCP with 15 Vetiver tillers the reduction was $54 \%$, while it was $62 \%$ for 30 Vetiver tillers. So it is shown that with the increase of the number of initial Vetiver tillers the uptake will increase, because more root surface is available for bacterial growth, and also the plant can absorb more nutrients.

Chemical oxygen demand (COD) is oxygen requirement to decompose organic and inorganic materials through chemical pathways. High COD level indicates the toxic condition and the presence of biologically resistant organic substances. Effects of two parameters' concentration and Vetiver density on COD reduction were investigated as follows.

3.4. Effect of Concentration on COD Reduction. The COD reduction increased significantly during the growing time, because the root system developed well. As shown in Figure 5, LCP had the highest COD reduction, up to $90 \%$, while phytoremediation in HCP showed lower COD reduction up to $30 \%$. Phytoremediation in LCP was more effective than in $\mathrm{HCP}$ as it shows more reduction of BOD and COD during remediation.
TABLE 5: Reduction of COD in high concentration POME with different Vetiver density.

\begin{tabular}{lccc}
\hline POME/Vetiver & COD day 0 & $\begin{array}{c}\text { COD after 14 } \\
\text { days }\end{array}$ & $\begin{array}{c}\text { COD } \\
\text { reduction \% }\end{array}$ \\
\hline Control & 763 & 686 & 10 \\
HCP/V30 & 721 & 440.3 & 39 \\
HCP/V15 & 784 & 548.2 & 30 \\
\hline
\end{tabular}

TABLE 6: Reduction of COD in low concentration POME with different Vetiver density.

\begin{tabular}{lccc}
\hline POME/Vetiver & COD day 0 & $\begin{array}{c}\text { COD after 14 } \\
\text { days }\end{array}$ & $\begin{array}{c}\text { COD } \\
\text { reduction } \%\end{array}$ \\
\hline Control & 114 & 100.3 & 12 \\
LCP/V30 & 102 & 6.1 & 94 \\
LCP/V15 & 113 & 29.3 & 74 \\
\hline
\end{tabular}

3.5. Effect of Vetiver Density on COD Reduction. As shown in Tables 5 and 6 the highest reduction of COD was for LCP with 30 Vetivers tiller, with $94 \%$ removed, while at the same concentration but with 15 Vetiver tillers the COD reduction was $74 \%$. Same as BOD results, with increasing Vetiver tillers the reduction efficiency increased. In HCP, with 15 Vetiver tillers the COD reduction was $30 \%$, while at this concentration with 30 Vetiver tillers the reduction increased to $39 \%$.

During the entire time series analysis, it can be shown that the concentration of BOD and COD of experimental sets planted with Vetiver was lower than that of the control set. This clearly shows the beneficial effect of Vetiver in treating POME. Comparing results with other studies showed that 
the range of COD reduction is between 16.5 and $98 \%$, for different types of wastewater and macrophytes.

None of the reported studies have used Vetiver on aerobic POME treatment. Due to the lack of studies in the field of Vetiver wastewater treatment, the results were compared with other studies published between 1997 to 2014, that have been used different macrophytes such as: Typha angustifolia, Canna, Phragmites australis, Cyperus papyrus, Typha orientalis, Zizania aquatica, Iris australis, Scirpusgrossus, Phragmaties mauritianus, Canna iridiflora, for the treatment of industrial or domestic wastewater such as: pig farm, dairy, sugar factory, textile, tannery, septic tank, municipal, black water and grey water.

Kantawanichkul et al. [28] planted Vetiver to treat diluted settled pig farm wastewater in Thailand. They reported 78.8 reduction percent of COD. Jiang and Xinyuan [29] used floating and submerged and emerged plants in the zoo wastewater and they reported $44 \%$ reduction of COD. Ji et al. [30] studied treatment of oil products wastewater in China, with Phragmites australis; they reported $80 \%$ COD reduction. Ahmed et al. [31] reported $72 \%$ COD reduction for treatment of municipal sludge, in India, with Phragmites australis. Chan et al. [32] conducted a study in China, for treatment of municipal secondary wastewater, with Cyperus alternifolius; they reported 83.6\% COD reduction. Abdel-Shafy et al. [33] studied treatment of secondary greywater in Egypt, with Phragmites australis; they reported 65.9\% reduction of COD. Song et al. [34] reported $62.2 \%$ COD reduction for municipal wastewater treatment in China with Phragmites australis and Typha orientalis. Katsenovich et al. [35] studied treatment of secondary municipal wastewater treatment in El Salvador, with Typha angustifolia; they reported $65.18 \%$ reduction of COD. Zhai et al. [36] conducted a study for treatment of secondary wastewater treatment in China with Cyperus alternifolius; they reported 83.6-84.1\% COD reduction. Chang et al. [37] studied COD reduction of secondary municipal wastewater treatment with Typha latifolia and Canna indica, in China; they reported $64.15 \%$ COD reduction. Saeed et al. [38] studied secondary Tannery wastewater treatment with Phragmites australis, in Bangladesh; they reported 98\% COD reduction. Abou-Elela et al. [39] reported 92.2\% COD reduction for treatment of municipal wastewater in Egypt, with Canna, Phragmites, and Cyperus. Liao et al. [40] conducted a study with Vetiver and Cyperus alternifolius, in China, for treatment of pig farm wastewater; they reported 64\% COD reduction. Kaseva [41] reported $60 \%$ of COD reduction for tertiary municipal sludge treatment, with Typha latifolia and Phragmites mauritianus, in Tanzania. Chan et al. [32] studied treatment of secondary municipal wastewater, with Cyperus alternifolius, in China; they reported $70 \%$ COD reduction. Abdel-Shafy et al. [33] used Phragmites australis, for treatment of secondary black water, in Egypt; they reported 83.5\% COD reduction. Song et al. [34] studied municipal wastewater treatment with Phragmites australis and Typha oriental, in China; they reported $62.2 \%$ COD reduction. Njau and Mlay [42] studied treatment of textile wastewater, with Vetiver and Phragmites mauritianus, in Tanzania; they reported $46.2 \%$ COD reduction. Li et al. [43] used Typha angustifolia on lake water, in China; they reported 39.6-40.4\%
COD reduction. In another study conducted by Li et al. [44], they used Phragmites australis, for river water, in China; they reported 17.9\% COD reduction. Tang et al. [45] used Typha latifolia, in river water, in China; they reported 35\% COD reduction. Mburu et al. [46] studied treatment of secondary municipal wastewater, with Cyperus papyrus; in Kenya, they reported 42.7-43.89\% COD reduction. Christwardana and Soetrisnanto [47] reported 50\% of COD reduction for treatment of POME, in Indonesia, with water hyacinth. Hussain et al. [48] used Typha angustifolia and Phragmites, for treatment of domestic wastewater, in Saudi Arabia; they reported 48.15\% COD reduction. Katsenovich et al. [35] used Phragmites australis, for treatment of secondary wastewater, in El Salvador; they reported $56 \%$ of COD reduction. Rivas et al. [49] studied treatment of secondary wastewater, in Mexico, with Typha latifolia and Phragmites australis; they reported 68\% COD reduction. Chang et al. [37] studied COD reduction of secondary municipal wastewater treatment with Typha latifolia and Canna indica, in China; they reported $64.15 \%$ COD reduction.

Comparing results with other studies showed that the range of BOD reduction is between 15.4 and $98 \%$, for different types of wastewater and macrophytes. Liao et al. [40] studied pig farm wastewater treatment with Vetiver and Cyprus alternifolius, in China; they reported $68 \%$ BOD reduction. Njau and Mlay [42] reported $67.47 \%$ BOD reduction for textile wastewater treatment in Tanzania, with Vetiver and Phragmites mauritianus. Jinadasa et al. [50] conducted a study in Sri Lanka, for treatment of secondary municipal wastewater, with Typha angustifolia and Scirpus grossus; they reported 68.2\% BOD reduction. Abdel-Shafy et al. [33] used Phragmites australis, in order to treat secondary black water in Egypt; they reported 86.4\% BOD reduction. Song et al. [34] reported $70.4 \%$ BOD reduction on municipal wastewater treatment in China, with Phragmites australis and Typha orientalis. Weragoda et al. [51] reported 65.5\% BOD reduction for municipal wastewater treatment in Seri Lanka, with Typha angustifolia and Canna iridiflora. Mburu et al. [46] used Typha angustifolia and Canna iridiflora, in order to treat municipal wastewater, in Seri Lanka; they reported $65.5 \%$ BOD reduction. A study was conducted by Hussain et al. [48], in Saudi Arabia, in order to treat domestic wastewater, with Typha angustifolia and Phragmites; they reported $66 \%$ BOD reduction. In another study, Klomjek and Nitisoravut [52] reported $74.3 \%$ BOD reduction from municipal saline condition treatment, with Typha angustifolia, in Thailand. Ji et al. [30] used Phragmites australis, for treatment of oil products wastewater; they reported $88 \%$ BOD reduction. Ahmed et al. [31] conducted a study for treatment of secondary wastewater, with Phragmites australis, in India; they reported $90 \%$ BOD reduction. Chan et al. [32] reported $90 \%$ BOD reduction for secondary municipal wastewater treatment in China, with Cyprus alternifolius. Chen et al. [53] studied secondary municipal wastewater treatment in China, with Cyprus alternifolius; they reported $90 \%$ BOD reduction. Abdel-Shafy et al. [33] reported $86.4 \%$ BOD reduction from secondary black water treatment, with Phragmites australis, in Egypt. Katsenovich et al. [35] studied treatment of secondary municipal wastewater treatment in $\mathrm{El}$ 


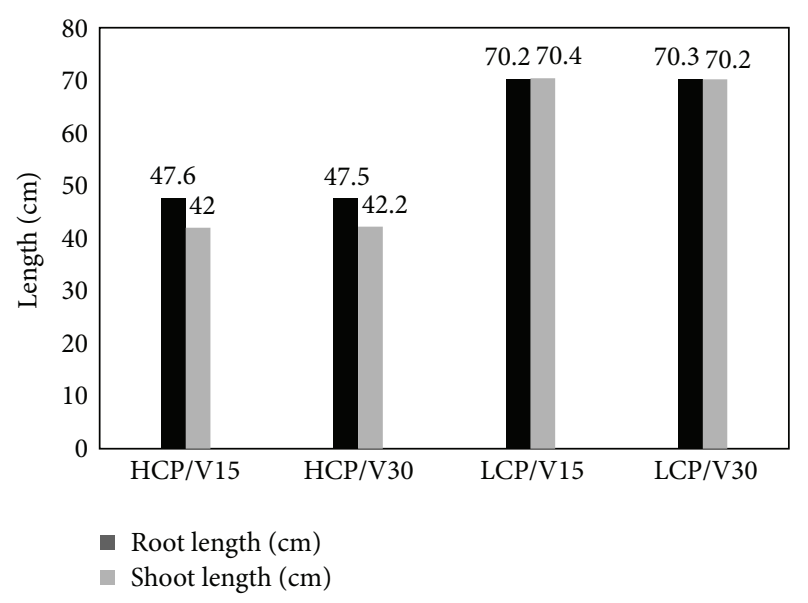

FIgURE 6: Root and shoot length of Vetiver $(\mathrm{cm})$ (HCP is high concentration POME and LCP is low concentration POME).

Salvador, with Typha angustifolia; they reported $80.78 \%$ BOD reduction. Saeed et al. [38] used Phragmites australis, in order to treat secondary tannery wastewater, in India; they reported $98 \%$ BOD reduction. Chang et al. [37] studied BOD reduction of secondary municipal wastewater treatment with Typha latifolia and Canna indica, in China; they reported $89.3 \%$ BOD reduction. Abou-Elela et al. [39] reported 93.6\% BOD reduction for treatment of municipal wastewater in Egypt, with Canna, Phragmites, and Cyperus. Li et al. [44] used Phragmites australis, for river water, in China; they reported $15.4 \%$ BOD reduction. Katsenovich et al. [35] studied treatment of secondary municipal wastewater treatment in El Salvador, with Typha angustifolia; they reported $22 \%$ reduction of BOD. Rivas et al. [49] studied treatment of secondary wastewater, in Mexico, with Typha latifolia and Phragmites australis; they reported 52\% BOD reduction. Mburu et al. [46] reported 52.98-60.93\% BOD reduction, for treatment of secondary municipal wastewater, with Cyperus papyrus; in Kenya.

The observed differences in reduction efficiencies with literatures could be due to differences in method of Vetiver application such as soil as a growing medium or hydroponic system with no supporting medium. Furthermore another factor such as the variation of wastewater concentration of wastewater, setting up the hydroponic system in an open space or green house, hydraulic retention time (HRT), quantity of Vetiver applied and temperature could alter the result.

3.6. Morphological Parameters. Growth parameters results such as shoot length, root length, number of leaves, and number of tillers in Vetiver in 14 days are given in Figures 6 to 8 . The root length showed a higher increase in LCP in both densities, rather than HCP. The maximum root length was $70 \mathrm{~cm}$ in LCP where the root length in $\mathrm{HCP}$ was $47 \mathrm{~cm}$. The shoot length was maximum $70.3 \mathrm{~cm}$ in LCP, where the shoot length was $42 \mathrm{~cm}$ for HCP in both densities of plant. There was an increase in the number of leaves and tillers almost in all treatments. The increase in leaf number was 344 in LCP/V30 and 260 in LCP/V15 (Figure 7). The tiller number

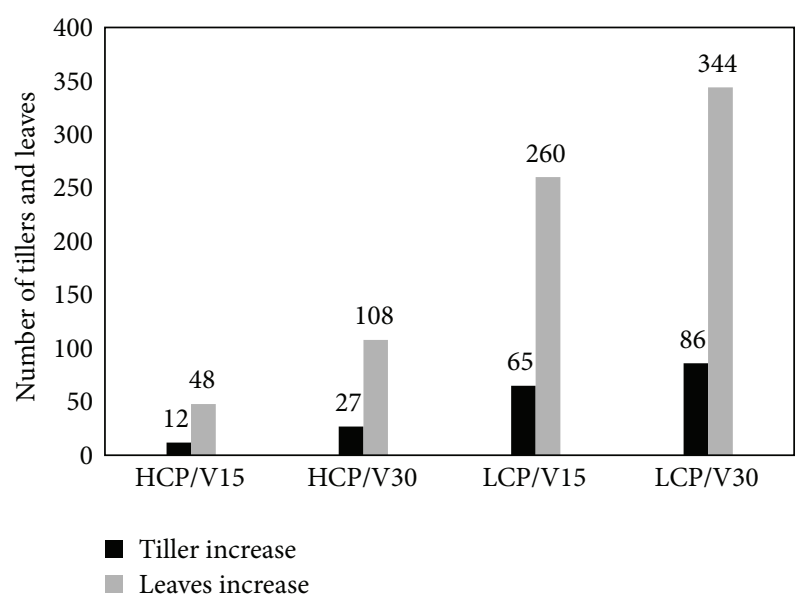

FIgURE 7: Tillers and leaves increase in Vetiver (HCP is high concentration POME and LCP is low concentration POME).

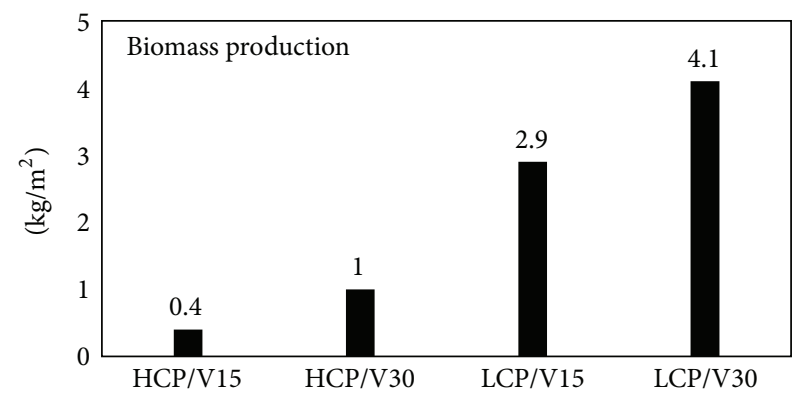

FIGURE 8: Biomass production of Vetiver $\left(\mathrm{kg} \mathrm{m}^{-2}\right)$ (HCP is high concentration POME and LCP is low concentration POME).

increased by 86 in the LCP/V30 treatment, which was highest among the treatments. The minimum tiller increase was 12 , which is seen in the HCP/V15 (Figure 8).

Biomass production of Vetiver increased with decrease in POME concentration. The maximum biomass production was $4.1 \mathrm{~kg} \mathrm{~m}^{-2}$ in LCP with 30 tillers and minimum biomass production was $0.4 \mathrm{~kg} \mathrm{~m}^{-2}$ in $\mathrm{HCP}$ with 15 tillers. Biomass production of Vetiver is given in Figure 9. The leaves of Vetiver are used for mulching, mat weaving, making basketry, animal fodder, and roof thatching.

\section{Conclusion}

Results showed that under hydroponic conditions for 2 weeks, Vetiver plants with well-developed root and shoots were able to reduce the BOD up to $90 \%$ in low concentration POME and $60 \%$ in high concentration POME, while control sets (without plant) only was able to reduce $15 \%$ of BOD. The COD reduction was $94 \%$ in low concentration POME and $39 \%$ in high concentration POME, while control just shows reduction of $12 \%$. Morphological parameter shows that highest root and shoot length number of tillers and leaves and biomass production were $70(\mathrm{~cm}), 70(\mathrm{~cm}), 86,344$, and $4.1 \mathrm{~kg} \mathrm{~m}^{-2}$, respectively. These results showed that Vetiver system technology (VST) was effective in reducing BOD and 


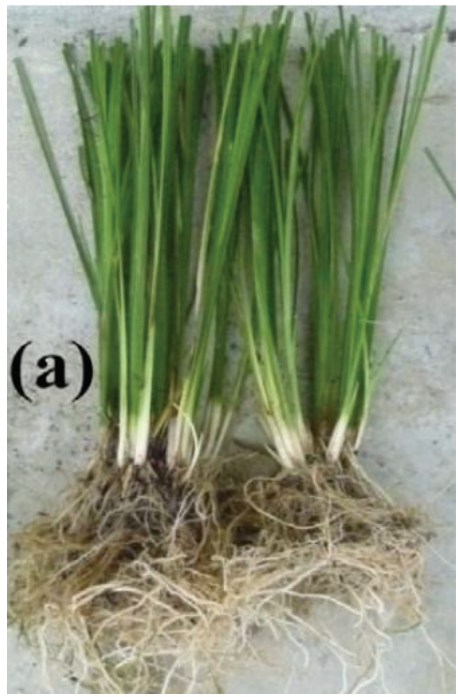

(a)

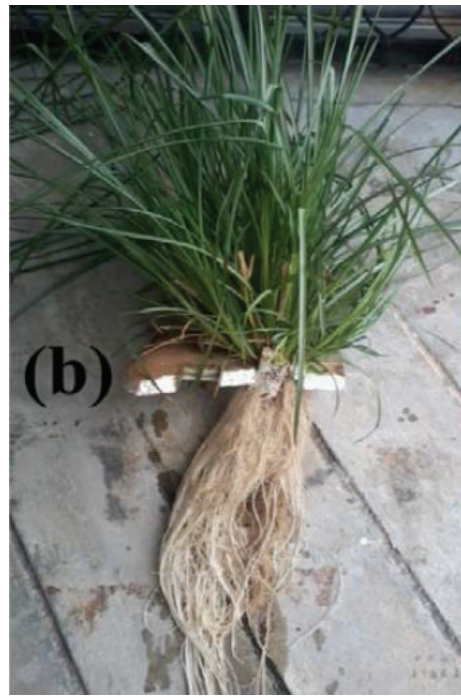

(b)

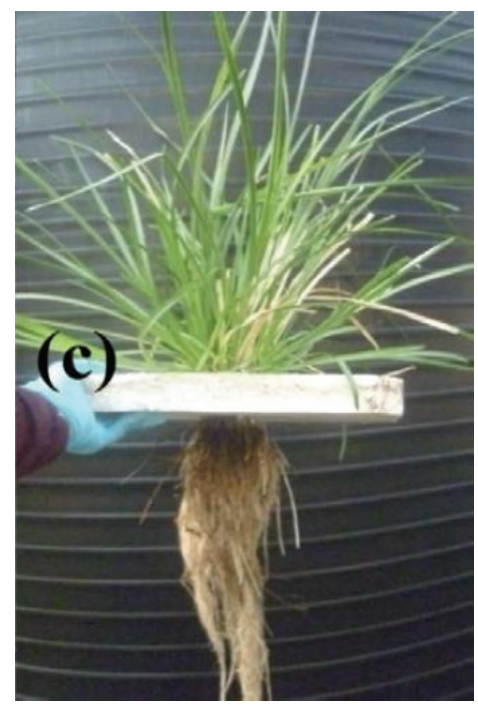

(c)

FIgURE 9: Vetiver growing on POME: (a) Vetiver starting day, (b) low concentration POME, and (c) high concentration POME.

COD in POME. The treatment in low concentration was superior to the high concentration. Furthermore, biomass of plant can be considered as a promising raw material for biofuel production while high amount of biomass was generated in low concentration of POME.

\section{Conflict of Interests}

The authors declare that there is no conflict of interests regarding the publication of this paper.

\section{Acknowledgment}

The authors acknowledge the Malaysian Palm Oil Board (MPOB) for providing research fund and facilities.

\section{References}

[1] G. Morrison, O. S. Fatoki, L. Persson, and A. Ekberg, "Assessment of the impact of point source pollution from the Keiskammahoek Sewage Treatment Plant on the Keiskamma River-pH, electrical conductivity, oxygen- demanding substance (COD) and nutrients," Water SA, vol. 27, no. 4, pp. 475480, 2001.

[2] X. Zhuang, J. Chen, H. Shim, and Z. Bai, "New advances in plant growth-promoting rhizobacteria for bioremediation," Environment International, vol. 33, no. 3, pp. 406-413, 2007.

[3] K. Vijayaraghavan, D. Ahmad, and M. Ezani Bin Abdul Aziz, "Aerobic treatment of palm oil mill effluent," Journal of Environmental Management, vol. 82, no. 1, pp. 24-31, 2007.

[4] Y. J. Chan, M. F. Chong, and C. L. Law, "Biological treatment of anaerobically digested palm oil mill effluent (POME) using a Lab-Scale Sequencing Batch Reactor (SBR)," Journal of Environmental Management, vol. 91, no. 8, pp. 1738-1746, 2010.

[5] T. Hwang, S. Ong, C. Seow, and H. Tan, "Chemical composition of palm oil mill effluents,” Planter, vol. 54, 1978.
[6] P. Agamuthu, "Palm oil mill effluent-treatment and utilization," in Waste Treatment Plant, pp. 338-360, Narosa Publishing House, New Delhi, India, 1995.

[7] A. L. Ahmad, S. Ismail, and S. Bhatia, "Water recycling from palm oil mill effluent (POME) using membrane technology," Desalination, vol. 157, no. 1-3, pp. 87-95, 2003.

[8] A. Ma, "Treatment of palm oil mill effluent," in Oil Palm and the Environment: A Malaysian Perspective, pp. 113-126, Malaysian Oil Palm Growers Council, Kuala Lumpur, Malaysia, 1999.

[9] P. F. Rupani, R. P. Singh, M. H. Ibrahim, and N. Esa, "Review of current palm oil mill effluent (POME) treatment methods: vermicomposting as a sustainable practice," World Applied Sciences Journal, vol. 11, pp. 70-81, 2010.

[10] J.-H. Tay, “Complete reclamation of oil palm wastes," Resources, Conservation and Recycling, vol. 5, no. 4, pp. 383-392, 1991.

[11] A. Ma, S. Cheah, M. Chow, and B. Yeoh, "Current status of palm oil processing wastes management," in Waste Management in Malaysia: Current Status and Prospects for Bioremediation, pp. 111-136, 1993.

[12] A. L. Ahmad, M. F. Chong, and S. Bhatia, "Mathematical modeling of multiple solutes system for reverse osmosis process in palm oil mill effluent (POME) treatment," Chemical Engineering Journal, vol. 132, no. 1-3, pp. 183-193, 2007.

[13] A. Ma, Y. Tajima, M. Asahi, and J. Hanif, "Effluent treatmentevaporation method," PORIM Engineering News, vol. 44, pp. 7-8, 1997.

[14] P. N. Truong, Y. K. Foong, M. Guthrie, and Y.-T. Hung, "Phytoremediation of heavy metal contaminated soils and water using vetiver grass," in Environmental Bioengineering, vol. 11 of Handbook of Environmental Engineering, pp. 233-275, Springer, 2010.

[15] A. M. Paz-Alberto and G. C. Sigua, "Phytoremediation: a green technology to remove environmental pollutants," American Journal of Climate Change, vol. 2, pp. 71-86, 2013.

[16] T. Macek, K. Francová, L. Kochánková et al., "Phytoremediation: biological cleaning of a polluted environment," Reviews on Environmental Health, vol. 19, no. 1, pp. 63-82, 2004. 
[17] S. Wagner, P. Truong, A. Vieritz, and C. Smeal, "Response of vetiver grass to extreme nitrogen and phosphorus supply," in Proceedings of the 3rd International Conference on Vetiver and Exhibition, Guangzhou, China, 2003.

[18] P. Truong, "Research and development of the vetiver system for treatment of polluted water and contaminated land," in TVN India 1st Workshop Proceedings, pp. 60-71, 2008.

[19] P. Truong, "Clean water shortage: an imminent global crisis. How vetiver system can reduce its impact," 2003.

[20] C. Smeal, M. Hackett, and P. Truong, "Vetiver system for industrial wastewater treatment in Queensland, Australia," in Proceedings of the 3rd International Conference on Vetiver and Exhibition, Guangzhou, China, 2003.

[21] L.-Y. Zhang, L. Zhang, Y.-D. Liu, Y.-W. Shen, H. Liu, and Y. Xiong, "Effect of limited artificial aeration on constructed wetland treatment of domestic wastewater," Desalination, vol. 250, no. 3, pp. 915-920, 2010.

[22] H. Dong, Z. Qiang, T. Li, H. Jin, and W. Chen, "Effect of artificial aeration on the performance of vertical-flow constructed wetland treating heavily polluted river water," Journal of Environmental Sciences, vol. 24, no. 4, pp. 596-601, 2012.

[23] M. Kumari and B. D. Tripathi, "Effect of aeration and mixed culture of Eichhornia crassipes and Salvinia natans on removal of wastewater pollutants," Ecological Engineering, vol. 62, pp. 48-53, 2014.

[24] C. Tanner, "Plants as ecosystem engineers in subsurface-flow treatment wetlands," Water Science and Technology, vol. 44, pp. 11-12, 2001.

[25] J. Vymazal and L. Kröpfelová, "Removal of organics in constructed wetlands with horizontal sub-surface flow: a review of the field experience," Science of the Total Environment, vol. 407, no. 13, pp. 3911-3922, 2009.

[26] S. Jouanneau, L. Recoules, M. J. Durand et al., "Methods for assessing biochemical oxygen demand (BOD): a review," Water Research, vol. 49, no. 1, pp. 62-82, 2014.

[27] B. Nagel, H. Dellweg, and L. Gierasch, "Glossary for chemists of terms used in biotechnology (IUPAC Recommendations 1992)," Pure and Applied Chemistry, vol. 64, pp. 143-168, 1992.

[28] S. Kantawanichkul, S. Pilaila, W. Tanapiyawanich, W. Tikampornpittaya, and S. Kamkrua, "Wastewater treatment by tropical plants in vertical-flow constructed wetlands," Water Science and Technology, vol. 40, no. 3, pp. 173-178, 1999.

[29] Z. Jiang and Z. Xinyuan, "Treatment and utilization of wastewater in the Beijing Zoo by an aquatic macrophyte system," Ecological Engineering, vol. 11, no. 1-4, pp. 101-110, 1998.

[30] G. D. Ji, T. H. Sun, and J. R. Ni, "Surface flow constructed wetland for heavy oil-produced water treatment," Bioresource Technology, vol. 98, no. 2, pp. 436-441, 2007.

[31] S. Ahmed, V. Popov, and R. C. Trevedi, "Constructed wetland as tertiary treatment for municipal wastewater," Proceedings of the ICE-Waste and Resource Management, vol. 161, no. 2, pp. 77-84, 2008.

[32] S. Y. Chan, Y. F. Tsang, H. Chua, S. N. Sin, and L. H. Cui, "Performance study of vegetated sequencing batch coal slag bed treating domestic wastewater in suburban area," Bioresource Technology, vol. 99, no. 9, pp. 3774-3781, 2008.

[33] H. I. Abdel-Shafy, M. A. El-Khateeb, M. Regelsberger, R. ElSheikh, and M. Shehata, "Integrated system for the treatment of blackwater and greywater via UASB and constructed wetland in Egypt," Desalination and Water Treatment, vol. 8, no. 1-3, pp. 272-278, 2009.
[34] H.-L. Song, X.-N. Li, X.-W. Lu, and Y. Inamori, "Investigation of microcystin removal from eutrophic surface water by aquatic vegetable bed," Ecological Engineering, vol. 35, no. 11, pp. 1589$1598,2009$.

[35] Y. P. Katsenovich, A. Hummel-Batista, A. J. Ravinet, and J. F. Miller, "Performance evaluation of constructed wetlands in a tropical region," Ecological Engineering, vol. 35, no. 10, pp. 15291537, 2009.

[36] J. Zhai, H. W. Xiao, K. Kujawa-Roeleveld, Q. He, and S. M. Kerstens, "Experimental study of a novel hybrid constructed wetland for water reuse and its application in Southern China," Water Science and Technology, vol. 64, no. 11, pp. 2177-2184, 2011.

[37] J.-J. Chang, S.-Q. Wu, Y.-R. Dai, W. Liang, and Z.-B. Wu, “Treatment performance of integrated vertical-flow constructed wetland plots for domestic wastewater," Ecological Engineering, vol. 44, pp. 152-159, 2012.

[38] T. Saeed, R. Afrin, A. A. Muyeed, and G. Sun, "Treatment of tannery wastewater in a pilot-scale hybrid constructed wetland system in Bangladesh," Chemosphere, vol. 88, no. 9, pp. 10651073, 2012.

[39] S. I. Abou-Elela, G. Golinelli, A. S. El-Tabl, and M. S. Hellal, "Treatment of municipal wastewater using horizontal flow constructed wetlands in Egypt," Water Science and Technology, vol. 69, no. 1, pp. 38-47, 2014.

[40] X. Liao, S. Luo, Y. Wu, and Z. Wang, "Studies on the abilities of Vetiveria zizanioides and Cyperus alternifolius for pig farm wastewater treatment," in Proceedings of the 3rd International Conference on Vetiver and Exhibition, Guangzhou, China, 2003.

[41] M. Kaseva, "Performance of a sub-surface flow constructed wetland in polishing pre-treated wastewater-a tropical case study," Water Research, vol. 38, no. 3, pp. 681-687, 2004.

[42] K. Njau and H. Mlay, "Wastewater treatment and other research initiatives with vetiver grass," in Proceedings of the International Conference on Vetiver Grass, pp. 25-31, 2003.

[43] L. Li, Y. Li, D. K. Biswas, Y. Nian, and G. Jiang, "Potential of constructed wetlands in treating the eutrophic water: evidence from Taihu Lake of China," Bioresource Technology, vol. 99, no. 6, pp. 1656-1663, 2008.

[44] M. Li, Y.-J. Wu, Z.-L. Yu, G.-P. Sheng, and H.-Q. Yu, "Enhanced nitrogen and phosphorus removal from eutrophic lake water by Ipomoea aquatica with low-energy ion implantation," Water Research, vol. 43, no. 5, pp. 1247-1256, 2009.

[45] X. Tang, S. Huang, M. Scholz, and J. Li, "Nutrient Removal in pilot-scale constructed wetlands treating eutrophic river water: assessment of plants, intermittent artificial aeration and polyhedron hollow polypropylene balls," Water, Air, and Soil Pollution, vol. 197, no. 1-4, pp. 61-73, 2009.

[46] N. Mburu, S. M. Tebitendwa, D. P. L. Rousseau, J. J. A. van Bruggen, and P. N. L. Lens, "Performance evaluation of horizontal subsurface flow-constructed wetlands for the treatment of domestic wastewater in the tropics," Journal of Environmental Engineering, vol. 139, no. 3, pp. 358-367, 2013.

[47] M. Christwardana and D. Soetrisnanto, "Phytoremediations of Palm Oil Mill Effluent (POME) by using aquatic plants and microalge for biomass production," Journal of Environmental Science and Technology, vol. 6, no. 2, pp. 79-90, 2013.

[48] G. Hussain, A. I. Al-Zarah, and A. S. Alquwaizany, "Role of Typha (Cattail) and Phragmites austrailes (Reed Plant) in domestic wastewater treatment," Research Journal of Environmental Toxicology, vol. 8, no. 1, pp. 25-36, 2014. 
[49] A. Rivas, I. Barceló-Quintal, and G. E. Moeller, "Pollutant removal in a multi-stage municipal wastewater treatment system comprised of constructed wetlands and a maturation pond, in a temperate climate," Water Science and Technology, vol. 64, no. 4, pp. 980-987, 2011.

[50] K. B. S. N. Jinadasa, N. Tanaka, M. I. M. Mowjood, and D. R. I. B. Werellagama, "Free water surface constructed wetlands for domestic wastewater treatment: a tropical case study," Chemistry and Ecology, vol. 22, no. 3, pp. 181-191, 2006.

[51] S. K. Weragoda, K. B. S. N. Jinadasa, D. Q. Zhang et al., "Tropical application of floating treatment wetlands," Wetlands, vol. 32, no. 5, pp. 955-961, 2012.

[52] P. Klomjek and S. Nitisoravut, "Constructed treatment wetland: a study of eight plant species under saline conditions," Chemosphere, vol. 58, no. 5, pp. 585-593, 2005.

[53] Z. M. Chen, B. Chen, J. B. Zhou et al., "A vertical subsurface-flow constructed wetland in Beijing," Communications in Nonlinear Science and Numerical Simulation, vol. 13, no. 9, pp. 1986-1997, 2008. 

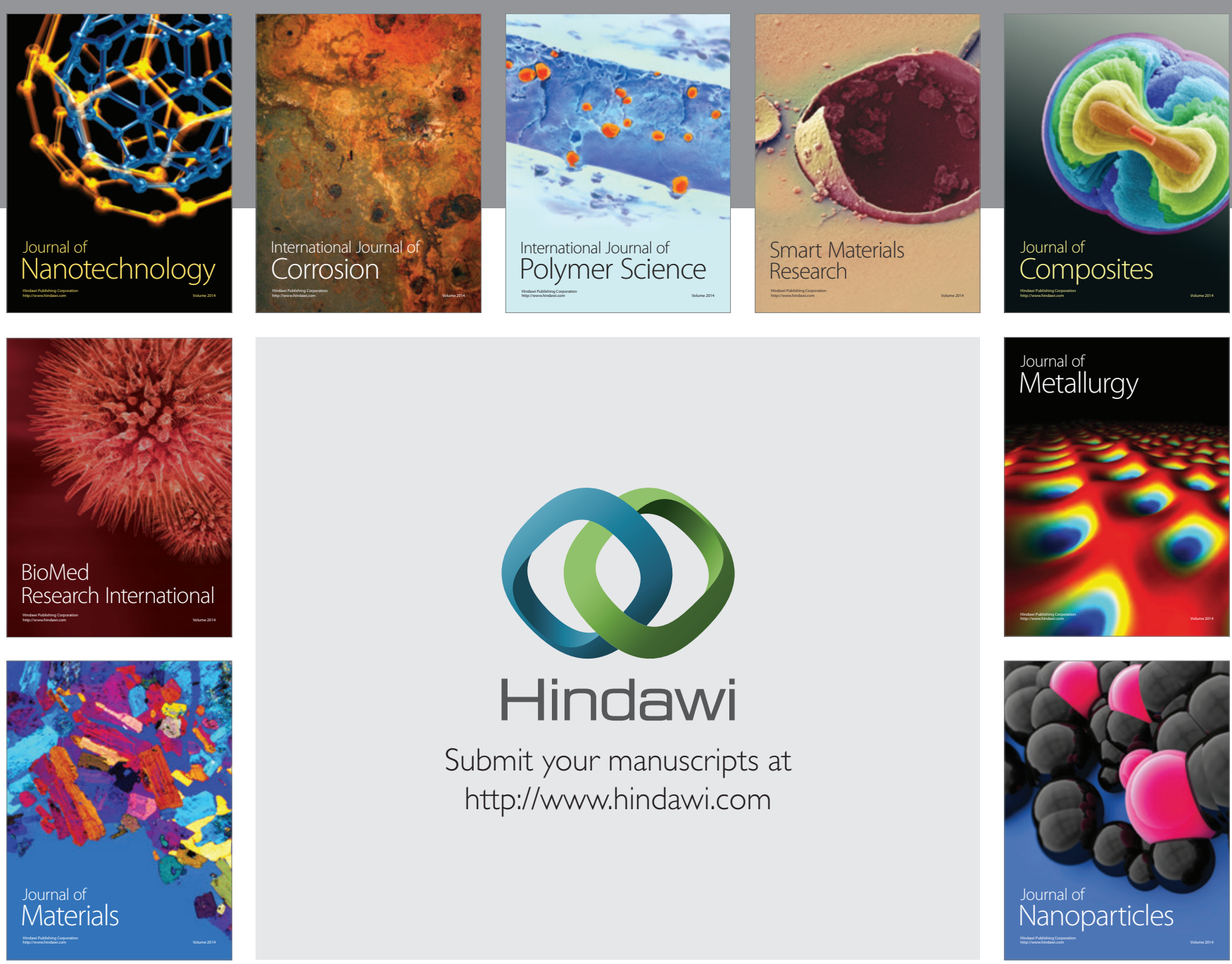

Submit your manuscripts at http://www.hindawi.com
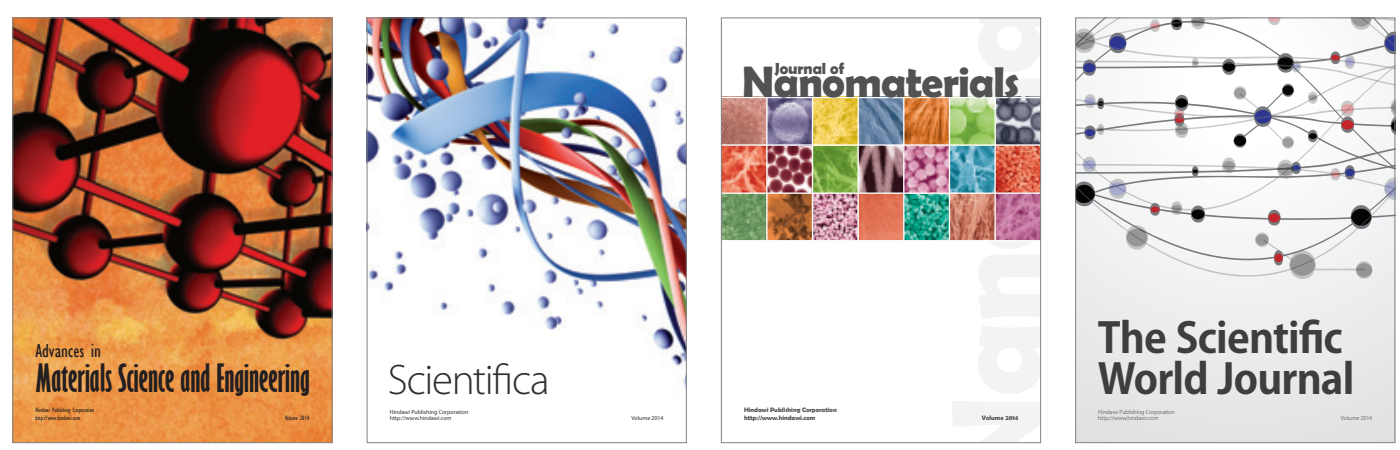

\section{The Scientific World Journal}
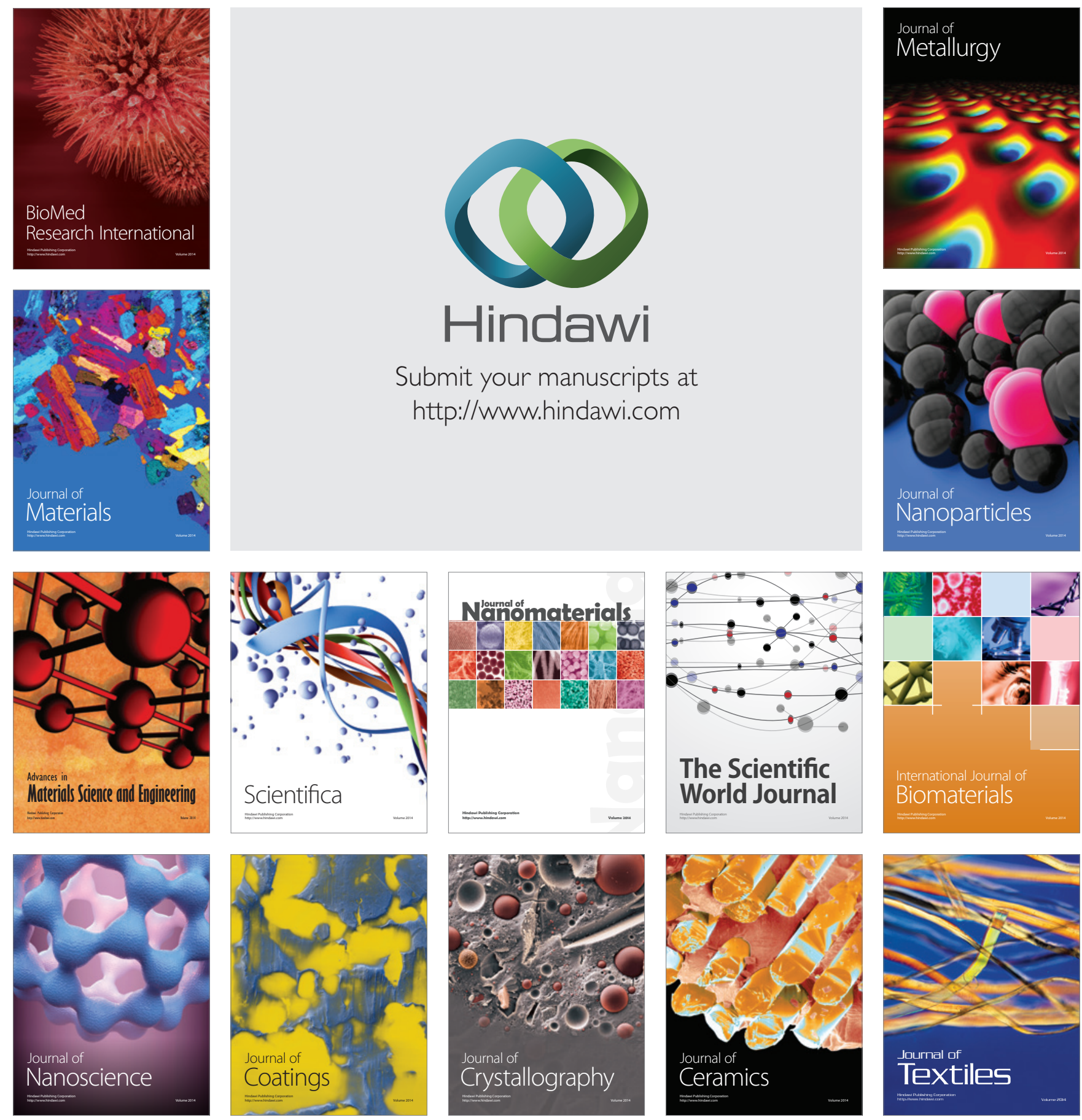